\title{
Preharvest Factors Influencing Postharvest Quality of Tropical and Subtropical Fruit
}

\author{
Mary Lu Arpaia \\ Department of Botany and Plant Sciences, University of California, Riverside, CA 92521-0124
}

The goal for postharvest physiologists, whether they are working in basic or applied research, is to maximize the postharvest quality of horticultural commodities. Quality relates to several factors that can be commodity specific and mean different things to different people. The consumer may perceive quality as it relates to appearance, flavor, and dollar value. The packinghouse handler, wholesale distributor, and retailer, in contrast, may perceive quality as ease of handling, uniformity of packaging, and freedom from physical and physiological defects as well as pathological breakdown. Although there is much to learn about the mechanisms of a given tropical or subtropical fruit's response to the postharvest environment, past research has provided handlers with the general principles of sound commodity management. These principles include temperature, relative humidity, atmosphere modification, cooling, and judicious use of fungicides and waxes following harvest. These management strategies are of critical importance for tropical products given their long transit conditions and the potential need for postharvest insect disinfestation quarantine treatments.

This paper will examine the role of the preharvest environment and how it may affect the postharvest life of tropical and subtropical fruit. Essentially, preharvest factors can influence both the rate of fruit development and maturation. The preharvest environment can also have a physical impact on fruit quality: for example, wind or insect scarring may reduce the packout percentage. Finally and most important, but much more difficult to quantify, are those effects that influence susceptibility to physiological and pathological breakdown. This review will not dwell on the latter, but recognizes that the influence of preharvest factors on postharvest decay incidence and severity has been well documented.

One must remember that the plant exists in a dynamic environment and therefore can respond to changes to that environment in an interactive fashion. The factors listed in Table 1 are neither all inclusive nor mutually exclusive. Several examples will illustrate the interaction between one or more preharvest factors on postharvest fruit quality.

\section{ENVIRONMENT}

Environmental factors include climate (temperature, wind, rainfall), air quality, and positional effects both within a planting and within the tree. Elements such as wind, heavy precipitation, and frost may result in direct loss of the fruit from the postharvest chain due to fruit scarring; increased incidence of plant pathogens associated with high rainfall, especially during flowering (i.e., anthracnose); and loss of fruit related to freeze damage. Temperature during fruit growth and maturation may also influence fruit quality by either hastening or delaying horticultural maturity.

In persimmons (Diospyros spp.), warmer temperatures both during early fruit development and just before harvest may influence the accumulation and subsequent turnover of tannins (Kitagawa and Glucina, 1984). Under cool growing conditions, incomplete tannin removal may result in inferior flavor development in nonastringent cultivars such as 'Fuyu'. High temperature during early growth also may influence fruit shape. In Japan, a study conducted under plastic illustrated that pummelos [Citrus grandis (L.) Osb.] grown under constant warm conditions tended to have large pear-shaped fruit with thicker peels and lower total soluble solids content (SSC) (Susanto and Nakajima, 1990).

Blackheart or endogenous brown spot (EBS), an important postharvest disorder of pineapple [Ananas comosus (L.) Merr.], has been related to both preharvest and postharvest temperature (Smith, 1983). EBS symptoms include small, brown translucent spots that form at the fruitlet base close to the core; there are no external symptoms. In their study conducted in Queensland, Australia, Smith and Glennie (1987) demonstrated the influence of field temperature and time before maturation (based on shell color). At constant growing conditions $<25 \mathrm{C}$, the incidence of this disorder increased at the time of harvest. Varying day/night temperatures $(25 \mathrm{C} / 15 \mathrm{C})$ to approximate the heat units of a constant exposure to $20 \mathrm{C}$ moderated this effect.

After mild freezes in California, avocado (Persea americana Mill.) fruit, although exhibiting no external damage, may become more susceptible to decay, weight loss, and chilling injury following storage. Relative susceptibility can be correlated to pedicel appearance following exposure to temperatures below $-1 \mathrm{C}$ in the field. This characteristic can be used as a marker of fruit quality at harvest following mild freezes (Arpaia, unpublished data).

In South Africa the incidence of grey pulp or mesocarp discoloration of avocados changes with time within a given growing district (Rowell, 1988). Rowell also documented differences in the amount of mesocarp discoloration related to growing districts, which also influence other quality aspects, such as the volatile oil content of navel orange. Bartholomew and Sinclair (1946) compared the warmer inland growing districts of California to a cooler growing district and found about a $25 \%$ reduction in volatile oil content in the cooler site.

Heat accumulation, expressed as heat units, may be a maturity index for 'Caraboa' mango (Mangifera indica L.) in the Philippines. One thousand heat units (degree-days above 17.9C) were required for proper fruit maturation. Temperature records from varying growing districts showed that the apparent difference in days to maturity could be explained by the difference in the rate of heat accumulation (Mendoza and Suriyapananont, 1984).

Rindstain of the peel is a major postharvest problem with California navel oranges [Citrus sinensis (L.) Osb.]. This disorder is influenced by several preharvest factors, including position on the tree. Fruit harvested from the north side of the tree showed a higher propensity to this disorder (Eaks, 1964). Tree positional effects on citrus fruit quality occur in relation to SSC, the SSC : titratable acidity (TA) ratio (Sites and Reitz, 1949, 1950), and epicuticular wax deposition and metabolism (El Otmani et al., 1989)

A good correlation between light and external fruit pigmentation development, a desirable quality attribute, exists for mango. Internal flesh breakdown (IFB), also known as jelly seed, soft nose, and tip pulp, of mangos is a leading postharvest problem for this fruit. Symptoms vary, but the occurrence is strongly cultivar dependent and may be genetically linked. Evidence also substantiates that large fruit size aggravates the occurrence of breakdown. For instance, 'Alphonso' mango had a $45 \%$ incidence of IFB in the largest fruit category compared to an $18 \%$ incidence in the smallest (Wainwright and Burbage, 1989).

Environmental conditions also influence susceptibility. In South Africa, Van Lelyveld and Smith (1979) reported that early season 'Sensation' mango had no IFB, whereas the incidence in late-season fruit was $80 \%$. There is a higher incidence of the disorder when fruit are harvested ripe as opposed to harvesting horticulturally mature but

Table 1. Preharvest factors involved in postharvest fruit quality.

\section{Climate/environment}

Rootstock/scion

Planting design

Pruning practices

Pest management

Irrigation

Plant growth regulators

Plant nutrition 
unripe fruit. Sun exposure after harvest also has been implicated in subsequent IFB development (Wainwright and Burbage, 1989).

Prasad et al. (1971) suggested that black tip, a related disorder in mangos, could be induced by sulfur dioxide emissions from local kilns in India, although they recognized there was substantial variation in cultivar susceptibility. Chandra and Yandagni (1984) reported that foliar sprays of sodium carbonate or borax could reduce tip pulp when the fruit were about the size of a marble.

Two physiological disorders of durian (Durio zibethinus Murr.), dry hard pulp and watery pulp, have been attributed to environmental conditions (Lim, 1990). Watery pulp is characterized by watery, dulltasting flesh surrounding the seed and is closely associated with fruit that matures and ripens during the rainy season.

\section{ROOTSTOCK/SCION}

Bitters and Scora (1970) demonstrated that citrus rootstock could influence both the yield and composition of the volatile peel oil. They documented that there was $\approx 40 \%$ difference in the yield of volatile oil between the two extreme rootstocks in the study. They also observed that the D-limonene content of the oil varied with rootstock. Kesterson et al. (1974) reported that lemon [Citrus limon (L.) Burm. f.] selection significantly affected peel oil yield $(\approx 25 \%$ difference between two extreme scions). Labanauskas (1969) reported that fruit size, juice content, and ascorbic acid content of 'Valencia' orange was higher when the fruit was grown on sweet orange rather than rough lemon rootstock. He also reported significant rootstock effects on the macroand micronutrient levels in citrus fruit.

Rootstock also affects the incidence of navel orange rindstain. Eaks and Jones (1959) reported the incidence of this disorder ranged from $64 \%$ in navel oranges on Rubidoux sour orange rootstock to $20 \%$ on Duncan grapefruit rootstock. Eaks and Arpaia (unpublished data) also have observed variability between navel orange strains in terms of their ability to withstand Mediterranean fruit fly disinfestation cold treatments during quarantine. Strain differences were moderated by preharvest application of gibberellin $\left(\mathrm{GA}_{3}\right)$. Kremer-Köhne and Köhne (1992) illustrated the influence of 'Fuerte' vs. 'Hass' avocado on susceptibility to chilling injury. They observed that 'Hass' had a higher percentage of fruit free from physiological disorders following storage than did 'Fuerte'.

\section{PLANTING DESIGN AND PRUNING}

Pruning practices may influence fruit maturation by allowing more light to reach the interior fruit. In navel orange, Boswell et al. (1982) demonstrated that tree spacing influenced the rate of fruit maturation as determined by SSC : TA ratio and color development. A critical consideration for tropical and subtropical fruits is also the timing of pruning. If pruning or girdling occurs at a time that promotes vegetative growth at the expense of fruit growth, a $\mathrm{Ca}$ imbalance and reduction in overall fruit size may occur. Whiley et al. (1992) reported higher fruit Ca levels during the first 8 weeks of 'Hass' avocado fruit growth when the spring vegetative flush was controlled with the growth regulator $\beta$-[(4-chlorophenyl)methyl]- $\alpha$-(1,1-dimethyl)- $1 H$ 1,2,4-triazole-1-ethanol (paclobutrazol). Cutting and Bower (1992) demonstrated, under the subtropical growing conditions of South Africa, that avocado fruit borne on trees where vegetative growth was controlled by pruning had higher $\mathrm{Ca}, \mathrm{Mg}, \mathrm{K}$, and $\mathrm{P}$ levels at harvest.

\section{PEST MANAGEMENT}

Pest management practices may result in direct fruit loss from scarring and in indirect losses from changes in fruit composition. Eaks and Dawson (1979) documented the influence of weed management practices on Valencia orange chlorophyll loss and carotenoid development. Fruit on trees maintained on bare ground showed a significantly lower amount of chlorophyll and higher amounts of carotenoids in its peel at all times. This finding can be related to the known effect of ground cover on lowering the soil temperature in the grove.

Lim and Khoo (1990) reported that direct loss of guava (Psidium guajara L.) fruit quality can be attributed to pesticide application.
They reported scorching of guavas resulting from the herbicide 1,1'dimethyl-4,4'-bipyridinium (paraquat). In some cultivars, $\mathrm{Cu}$ sprays for decay control can induce russet formation on the fruit surface. Fruit at all stages of development are susceptible. They also reported that russeting may influence the storage quality of the fruit. Beck et al. (1991) demonstrated that applying phosphorothioic acid $O, O$-diethyl $O$-(3,5,6-trichloro-2-pydridinyl)ester (chlorpyrifos), an organophosphate, at the time of carpel initiation could affect grapefruit (Citrus paradisi Macfad.) morphology by stimulating chimeral-type ridges on the fruit.

Thrips scarring, caused by second instar feeding of the citrus thrips on young, developing navel orange fruit, is a major concern for growers and is the number one pest controlled in navel orange in California (Arpaia and Morse, 1991). The occurrence of thrips scarring on the fruit results in direct fruit loss as a result of downgrading at the packinghouse. Arpaia and Morse (1991) examined the impact of using less pesticides on subsequent fruit quality affected by varying levels of citrus thrips scarring. They found that fruit with moderate or severe scarring had higher levels of SSC, lower TA, higher SSC : TA ratios, and greater weight loss. In a subsequent study (Arpaia and Morse, unpublished data), they found that the more heavily scarred fruit reached the legal minimum 8 SSC : 1 TA ratio sooner than fruit with no or slight scarring. This differential was maintained through the sampling period.

In the Philippines, mangos are often bagged to reduce the amount of damage from leafhoppers. Ortega (1983) compared the effectiveness of various coverings to control pests. He found that fruit bag material also influenced fruit quality, an indirect loss due to a pest management practice. Covering fruit with paper $\approx 55$ days from flowering resulted in less anthracnose and stem-end rots. Conversely, fruit covered with polyethylene resulted in more decay and increased fruit softening. This softening was attributed to higher fruit temperature and relative humidity in the polyethylene bag.

\section{IRRIGATION}

Irrigation effects on postharvest fruit quality are difficult to quantify. However, George (1987) documented that 'Apen' banana (Musa $\times$ paradisica L.) subjected to water stress during growth had a significantly shorter storage life. He also reported that $\mathrm{GA}_{3}$ application can increase storage life only when bananas are maintained under high relative humidity during storage. Bower (1988) found that preharvest water stress influenced polyphenol oxidase (PPO) levels in ripe avocado fruit after 30 days in storage at 5.5C. PPO has been associated with mesocarp discoloration in avocados. He also found that preharvest water stress influences the fruit's ability to withstand low $\mathrm{O}_{2}$ and high $\mathrm{CO}_{2}$. Fruit from stressed trees exhibited more physiological disorders following storage and ripening than fruit from nonstressed trees.

SSC and percent juice content at harvest of navel orange trees were affected by varying irrigation regimes. Fruit harvested from wellirrigated trees tended to have higher SSC and higher juice content. Irrigation practices also had a seasonal effect on the fruit's relative tolerance to an insect disinfestation quarantine cold treatment (Arpaia and Eaks, 1990).

\section{PLANT GROWTH REGULATORS}

Several researchers have reported the impact of exogenously applied plant growth regulators on postharvest fruit quality. External pigmentation of litchi (Litchi sinensis Sonn.) is an important determinant of fruit quality. Deep-red pigmentation is desirable in litchi cultivars. External quality within a cultivar can be influenced by growing region, light level, and overall nutrition (Underhill and Wong, 1990).

Jaiswal et al. (1987) studied the effect of kinetin and cycloheximide on anthocyanin development in 'Kasba' litchi. Both materials were applied $\approx 3$ days before full color development. Total anthocyanin content of the litchi rind was significantly lowered by both materials and was concentration dependent. They also report that kinetin delayed chlorophyll degradation.

$\mathrm{GA}_{3}$, a widely used plant growth regulator, has well-documented 
effects on citrus fruit quality. Coggins (1969) demonstrated the positive effects of preharvest $\mathrm{GA}_{3}$ applications on maintaining peel firmness and delaying overall rind senescence. El-Otmani and Coggins (1991) observed that $\mathrm{GA}_{3}$ applications reduced wax deposition on the navel orange fruit surface and delayed the transition of the epicuticular wax structure from crystalline to amorphous.

Applying $\mathrm{GA}_{3}$ before color break reduced the incidence of navel orange rindstain (Coggins et al., 1963). Arpaia and Eaks (1990) have studied the effect of a preharvest $\mathrm{GA}_{3}$ application on navel orange susceptibility to chilling injury, specifically in response to an insect disinfestation quarantine cold treatment. Chilling injury development in navel oranges is largely restricted to the peel and is characterized by increased decay, and pitting and staining of peel tissue. A preharvest $\mathrm{GA}_{3}$ application at color break will reduce the fruit's susceptibility. The magnitude of the response depended on fruit maturity, with the greatest response observed in late-season navel oranges.

Garcia-Luis et al. (1985) examined the effect of $\mathrm{GA}_{3}$ on Satsuma mandarin (Citrus reticulata Blanco) fruit quality. They observed, as have others, that $\mathrm{GA}_{3}$ maintained peel resistance as compared to nontreated controls at both sampling dates. The effect of $\mathrm{GA}_{3}$ was concentration dependent. They also noted that fruit ripened more slowly (as indicated by external fruit color and peel chlorophyll content) with increased $\mathrm{GA}_{3}$ concentration. Most important, they observed a significant reduction in the percentage of fruit that were puffy, a senescence disorder affecting fruit marketability.

Preharvest $\mathrm{GA}_{3}$ applications also influence mango fruit quality (Khader, 1991). In this study, Khader obtained a slight but significant delay in the speed of fruit ripening associated with $\mathrm{GA}_{3}$ treatment. $\mathrm{He}$ noted that treated fruit had lower SSC, higher TA, and ascorbic acid at harvest and after 6 days of ripening. Treated fruit also had less total carotenoids and increased chlorophyll even after complete ripening. In an earlier study, Khader (1990) tested the response of mango fruit ripening to paclobutrazol. Paclobutrazol was applied twice, at the time of fruit bud differentiation and $\approx 20$ days before harvest. Trees treated at the higher concentrations flowered $\approx 1$ week before the control, and at harvest, they had significantly more color (less chlorophyll and greater carotenoids), SSC, and amylase activity. This effect was concentration dependent.

Andam (1980) studied the effect of ethephon on 'Caraboa' mango. He found that ethephon applied 40 to 54 days from flowering did not hasten maturation, but ethylene and respiratory activity was enhanced during the postharvest life of the fruit. Lertpuk and Mendoza (1988) reported that a preharvest ethephon application had no significant effect on the total postharvest life of 'Caraboa' mango.

\section{PLANT NUTRITION}

The amount of applied N influences volatile oil yield of 'Bearss' lemon (Kesterson et al., 1974; Koo et al., 1973). Koo et al. (1973) also reported that K influenced oil yield in a negative manner, but this effect was nonsignificant. Embleton and Jones (1968) reported that K affected lemon fruit quality; peel thickness, juice percent, TA, and ascorbic acid were related to leaf $\mathrm{K}$ content.

An interesting effect of preharvest plant nutrition on banana postharvest handling was elucidated by Johnson (1979). Water tanks are used at packing stations for conveying bananas to transport them within the packinghouse with minimal damage. The specific gravity of the banana is normally $<1.0$, but at times up to $5 \%$ of the fruit may sink to the bottom of the wash tanks. Fruit that sink are subject to more mechanical damage due to abrasion. Johnson found that the pulp $\mathrm{K}$ content of affected fruit was $36 \%$ lower than that of nonaffected fruit and that peel $\mathrm{K}$ differed by $20 \%$. He studied this in field experiments that involved varying levels of K nutrition. His results showed a $48 \%$ difference in the incidence of sinking fruit between the control and the $\mathrm{K}$ treatment.

Calyx separation is a disorder observed in persimmons (Diospyrus $k a k i$ L.f.) produced in New Zealand and has been related to excessive $\mathrm{N}$ levels and improperly timed fruit thinning (Glucina, 1987). High N also depressed color development in mangos. Potassium can counteract this effect, but excessively high levels of $\mathrm{K}$ may induce a $\mathrm{Ca}$ imbalance in the fruit. Calcium levels within mango fruit influence the development of internal flesh breakdown (Mercado, 1979; Smith, 1989).

Soft nose or tip pulp of mangos is a breakdown of the fruit flesh at the fruit apex. The severity of this disorder varies from season to season. Young and Miner (1961) illustrated that the incidence of soft nose was influenced by an interrelationship between high $\mathrm{N}$ and $\mathrm{Ca}$, with Ca tending to prevent or retard soft nose. Burdon et al. (1991) reported finding a gradient of $\mathrm{Ca}$ and $\mathrm{Mg}$ levels in fruit. The lowest levels of pulp Ca were in the area of the fruit normally associated with soft nose. When they compared tissue from affected and nonaffected areas, they found higher levels of $\mathrm{Ca}$ in affected tissue. They hypothesized that during symptom development $\mathrm{Ca}$ may be relocated to deficient areas.

Extensive research on 'Fuerte' avocado has been conducted in South Africa. This research focuses on the relationship of postharvest avocado fruit quality and the role of plant nutrition. Witney et al. (1990) demonstrated the impact of fruit Ca levels on fruit ripening duration. They reported a significant interaction between these two variables, with high-Ca fruit taking longer to ripen. They also reported on fruit $\mathrm{Ca}$ levels during fruit growth from vigorous vs. nonvigorous trees for both 'Hass' and 'Fuerte'. In both instances, fruit borne on nonvigorous trees had higher Ca levels, especially during the early stages of fruit growth. This period also correlates with the time of maximal vegetative flushing. They suggest that it is the early levels of $\mathrm{Ca}$ in the fruit that influence subsequent postharvest fruit quality. The work of Whiley et al. (1992) confirmed this observation.

Postharvest problems of avocados in South Africa are a combination of several disorders. Swarts (1984) differentiates between pulp spot and mesocarp discoloration or grey pulp. Pulp spot is a blackening of the pulp region surrounding cut vascular bundles and is localized in nature and more prevalent in early season fruit. Mesocarp discoloration or grey pulp is an overall grey-brown flesh discoloration that normally increases with fruit maturity. Vorster and Bezuidenhout (1988) reported lower $\mathrm{Zn}$ and Ca levels in fruit exhibiting pulp spot. More recently, Smith and Köhne (1992) surveyed a large population of 'Fuerte' avocado trees in which low-yielding trees had poorer fruit quality following storage and lower $\mathrm{Ca}$ and $\mathrm{Zn}$ levels and higher $\mathrm{B}$ levels in flesh tissue.

This picture is complicated by the recent multi-year study of du Plessis and Koen (1992). They concluded that the incidence of grey pulp (or mesocarp discoloration) is strongly correlated with the subsoil $\mathrm{Ca}$ and $\mathrm{Mg}: \mathrm{K}$ ratio. They also reported a significant reduction in the incidence of pulp spot with high levels of subsoil K, which, however, was found to aggravate grey pulp.

\section{CONCLUSIONS}

There is ample evidence in current literature that preharvest factors may influence the postharvest fruit quality of tropical and subtropical fruit. Preharvest factors are perhaps especially critical to the success of handling tropical and subtropical fruit since typically long transit times to market are required and fruit are subject to insect disinfestation treatments. Understanding the effects of the preharvest environment on growth and maturation processes and susceptibility to physiological and pathological disorders will help to explain inconsistencies in postharvest fruit performance for a given cultivar. There will also be an indirect benefit of this line of research. Typically, growers do not usually understand the postharvest biology of their particular commodity nor do they particularly care since they perceive that "postharvest" is anything past the farm gate. Efforts toward understanding the role of preharvest factors on postharvest quality brings growers into actively controlling the quality of their product and helps to make them willing participants in the quest for optimizing product quality.

\section{Literature Cited}

Andam, C.J. 1980. Effects of pre-harvest ethephon application on fruit retention, maturation and quality of 'Caraboa' mango (Magnifera indica L.). MS Thesis, Univ. of the Philippines at Los Banos College, Laguna.

Arpaia, M.L. and I.L. Eaks. 1990. The effect of cultural practices on the 
postharvest response of navel orange. 23rd Intl. Soc. Hort. Sci. Congr., Firenze, Italy, 27 Aug.-1 Sept. 1990. p. 678. (Abstr. 2494)

Arpaia, M.L. and J.G. Morse. 1991. Citrus thrips Scirtothrips citri (Moulton) (Thys., Thripidae) scarring and navel orange fruit quality in California. J. Appl. Entomol. 111:28-32.

Bartholomew, E.T. and W.B. Sinclair. 1946. The factors influencing the volatile oil content of the peel of immature and mature oranges. Plant Physiol. 21(3):319-331.

Beck, N.G., M.L. Arpaia, K.J. Eckard, J.S. Reints, Jr., and E.M. Lord. 1991. The effect of chlorpyrifos on flowers and fruit development in grapefruit, Citrus paradisi Macfayden. Sci. Hort. 47:35-50.

Bitters, W.P. and R.W. Scora. 1970. The influence of citrus rootstocks upon the volatile oil content of Valencia orange (Citrus sinensis Osbeck). Bot. Gaz. 131(2):105-109.

Boswell, S.B., E.M. Nauer, and D.R. Atkin. 1982. Effect of tree density on fruit quality, temperature, light penetration, growth, and production of old-line 'Atwood' navel orange trees. J. Amer. Soc. Hort. Sci. 107:60-65.

Bower, J.P. 1988. Pre- and postharvest measures for long-term storage of avocados. South African Avocado Growers' Assn. Yrbk. 11:68-72.

Burdon, J.N., K.G. Moore, and H. Wainwright. 1991. Mineral distribution in mango fruit susceptible to the physiological disorder soft-nose. Sci. Hort. 48:329-336.

Chandra, A. and R. Yamdagni. 1984. A note on the effect of borax and sodium carbonate sprays on the incidence of black-tip disorders in mango. Punjab Hort. J. 24:17-18.

Coggins, C.W., Jr. 1969. Gibberellin research on citrus rind aging problems, p. 1177-1185. In: H.D. Chapman (ed.). Proc. First Intl. Citrus Symp., Univ. of California, Riverside, 16-26 Mar. 1968.

Coggins, C.W., Jr., I.L. Eaks, H.Z. Hield, and W.W. Jones. 1963. Navel orange rind staining reduced by gibberellin $\mathrm{A}_{3}$. Proc. Amer. Soc. Hort. Sci. 83:154157.

Cutting, J.G.M. and J.P. Bower. 1992. The effect of vegetative pruning on fruit mineral composition and postharvest quality in 'Hass' avocado, p. 403407. In: C.J.Lovatt (ed.). Proc. World Avocado Congr. II, 21-26 Apr. 1991, Orange, Calif.

du Plessis, S.F. and T.J. Koen. 1992. Relationship between mineral nutrition and postharvest fruit disorders of 'Fuerte' avocados, p. 395-402. In: C.J. Lovatt (ed.). Proc. World Avocado Congr. II, 21-26 Apr. 1991, Orange, Calif.

Eaks, I.L. 1964. The effect of harvesting and packinghouse procedures on rindstaining of central California Washington navel oranges. Proc. Amer. Soc. Hort. Sci. 85:245-256.

Eaks, I.L. and A.J. Dawson. 1979. The effect of vegetative ground cover and ethylene degreening on 'Valencia' rind pigments. J. Amer. Soc. Hort. Sci. 104:105-109.

Eaks, I.L. and W.W. Jones. 1959. Rindstaining and breakdown of navels. Calif. Citrograph 44:390, 400, 402.

El-Otmani, M., M.L. Arpaia, C.W. Coggins, Jr., J.E. Pehrson, Jr., and N.V. O'Connell. 1989. Developmental changes in quantity and structure of 'Valencia' orange fruit epicuticular wax in relation to fruit position on the tree. Sci. Hort. 41:68-91.

El-Otmani, M. and C.W. Coggins, Jr. 1991. Growth regulator effects on retention of quality of stored citrus fruits. Sci. Hort. 45:261-272.

Embleton, T.W. and W.W. Jones. 1968. Potassium builds lemon quality. Better Crops with Plant Food 52(1):18-19.

Garcia-Luis, A., M. Agusti, V. Almela, E. Romero, and J.L. Guardiola. 1985. Effect of gibberellic acid on ripening and peel puffing in 'Satsuma' mandarin. Sci. Hort. 27:75-86.

George, J.B. 1987. Water stress and gibberellins: Effects on the storage of plaintains, p. 152-154. In: International cooperation for effective plaintain and banana research. Proc. 3rd Mtg., 27-31 May 1985, Abidjan, Ivory Coast.

Glucina, P.G. 1987. Calyx separation: A physiological disorder of persimmons. Orchards New Zealand 60:161-163.

Jaiswal, B.P., N.L. Sah, and U.S. Prasad. 1987. Regulation of colour break during litchi (Litchi chinensis Sonn.) ripening. Ind. J. Expt. Biol. 25:66-72.

Johnson, T.J. 1979. Effects of potassium on buoyancy of banana fruit. Expt. Agr. 15:173-176.

Kesterson, J.W., R.J. Braddock, and R.C.J. Khoo. 1974. The effect of budwood rootstock, irrigation, and fertilization on the yield of Florida lemon oil. Proc. Fla. State Hort. Soc. 87:6-9.

Khader, S.E.S.A. 1990. Orchard application of paclobutrazol on ripening, quality and storage of mango fruits. Sci. Hort. 41:329-335.

Khader, S.E.S.A. 1991. Effect of preharvest application of $\mathrm{GA}_{3}$ on postharvest behaviour of mango fruits. Sci. Hort. 47:317-321.
Kitigawa, H. and P.G. Glucina. 1984. Persimmon culture in New Zealand. DSIR Info. Ser. 159, Wellington, N.Z.

Koo, R.C.J., T.W. Young, R.L. Reese, and J.W. Kesterson. 1973. Responses of 'Bearss' lemon to nitrogen, potassium, and irrigation applications. Proc. Fla. State Hort. Soc. 86:9-12.

Kremer-Köhne, S. and J.S. Köhne. 1992. Yield and fruit quality of Fuerte and Hass on clonal rootstocks. South African Avocado Growers' Assn. Yrbk. 15:69.

Labanauskas, C.K. 1969. Constituents of Valencia orange. J. Amer. Diet. Assn. $55: 44-49$.

Lertpuk, S. and D.B. Mendoza, Jr. 1988. Postharvest life of 'Caraboa' mango (Magnifera indica L.) as affected by preharvest treatment of ethephon. Philippine Agr. 71:1-5.

Lim, L.T. 1990. Durian diseases and disorders. Tropical Press SDN.BHD., Kuala Lampur, Malaysia.

Lim, L.T. and K.C. Khoo. 1990. Guava in Malaysia: Production, pests and diseases. Tropical Press SDN.BHD., Kuala Lampur, Malaysia.

Mendoza, Jr., D.B. and V. Suriyapananont. 1984. Factors affecting growth and development of mango, p. 27-32. In: D.B. Mendoza, Jr., and R.B.H. Wills (eds.). Mango: Fruit postharvest physiology and marketing in ASEAN. Assn. Southeast Asian Nations Food Handling Bureau, Kuala Lampur, Malaysia.

Mercado, B.T. 1979. The relationship between nutritional status of the mango plant and its responsiveness to flower forcing treatments, p. 194-216. In: Flowering and fruiting research project on mango. Annu. Rpt., Univ. of the Philippines at Los Banos College, Laguna-Philippine Council for Agr. and Resources Res. Proj. 149.

Ortega, V.C. 1983. Bagging of mango fruits. 2nd Natl. Symp. Fruits, Philippine Council Agr. and Resources Res. and Development, Los Banos, Laguna. p. 53-58.

Prasad, A., M.D. Saran, and K. Singh. 1971. Black-tip disease of mango and its control. Hort. Adv. 8:4-10.

Rowell, A.W.G. 1988. Cold storage capacity of avocados from different geographic regions. South African Avocado Growers' Assn. Yrbk. 11:4147

Sites, J.W. and H.J. Reitz. 1949. The variation in individual 'Valencia' oranges from different locations on the tree as a guide to sampling method and spot picking for quality. Part 1 . Soluble solids in the juice. Proc. Amer. Soc. Hort. Sci. 54:1-10.

Sites, J.W. and H.J. Reitz. 1950. The variation in individual 'Valencia' oranges from different locations of the tree as a guide to sampling method and spot picking for quality. Part II. Titratable acid and the soluble solids/titratable acids ratio of the juice. Proc. Amer. Soc. Hort. Sci. 55:73-80.

Smith, B.L. 1989. Mango fertilizer trials: Preliminary results information. Bul., Citrus \& Subtropical Fruit Res. Inst., Nelspruit, South Africa. 197:4.

Smith, D.G. and J.S. Köhne. 1992. Production potential of Fuerte on seedling rootstocks. South African Avocado Grower's Assn. Yrbk. 15:83-85.

Smith, L.G. 1983. Cause and development of blackheart in pineapples. Trop. Agr. 60(1):31-35.

Smith, L.G. and J.D. Glennie. 1987. Blackheart development in growing pineapple. Trop. Agr. (Trinidad) 64(1):7-12.

Susanto, S. and Y. Nakajima. 1990. Effect of winter heating on flowering time, fruiting and fruit development in pummelo grown in a plastic house. J. Jpn. Soc. Hort. Sci. 59(2):245-253.

Swarts, D.H. 1984. Post-harvest problems of avocados-Let's talk the same language. South Africa Avocado Grower's Assn. Yrbk. 7:15-19.

Underhill, S.J.R. and L.S. Wong. 1990. A maturity standard for lychee (Litchi chinensis Sonn.) Acta Hort. 269:181-187.

Van Lelyveld, L.J. and J.H.E. Smith. 1979. Physiological factors in the maturation and ripening of mango (Mangifera indica $\mathrm{L}$.) fruit in relation to the jelly-seed physiological disorder. J. Hort. Sci. 54:283-287.

Vorster, L.L. and J.J. Bezuidenhout. 1988. Does zinc play a role in reducing pulp spot? South African Avocado Growers' Assn. Yrbk. 11:60.

Wainwright, H. and M.B. Burbage. 1989. Physiological disorders in mango (Mangifera indica L.) fruit. J. Hort. Sci. 64(2):125-135.

Whiley, A.W., J.B. Saranah, and B.N. Wolstenholme. 1992. Effect of paclobutrazol bloom sprays on fruit yield and quality of cv. Hass avocado growing in subtropical climates, p. 227-232. In: C.J. Lovatt (ed.). Proc. World Avocado Congr. II, 21-26 Apr. 1991, Orange, Calif.

Witney, G.W., P.J. Hofman, and B.N. Wolstenholme. 1990. Effect of cultivar, tree vigour and fruit position on calcium accumulation in avocado fruits. Sci. Hort. 44(3-4):269-278.

Young, T.W. and J.T. Miner. 1961. Relationship of nitrogen and calcium to "soft-nose" disorder in mango fruits. Proc. Amer. Soc. Hort. Sci. 78:201208. 